\title{
MOTIVASI DAN PENGALAMAN KERJA APARAT DESA DALAM PELAKSANAAN TUGAS PEMERINTAHAN DESA DI KECAMATAN PATTALLASSANG KABUPATEN GOWA
}

\section{MOTIVATION AND WORK EXPERIENCE OF VILLAGE OFFICIALS IN IMPLEMENTATION VILLAGE GOVERNMENT DUTIES IN PATTALLASSANG DISTRICT GOWA REGENCY}

\author{
Muh. Rizal S', Henni Zainal' ${ }^{2}$, Maya Kasmita ${ }^{3}$, Sirajuddin Saleh $^{4}$ \\ Universitas Negeri Makassar ${ }^{1,3,4}$ \\ Universitas Indonesia Timur, Makassar ${ }^{2}$ \\ Email: ${ }^{1}$ rizalsuyuti@unm.ac.id
}

\begin{abstract}
ABSTRAK: Motivasi dan pengalaman kerja yang dimiliki seorang aparat desa dalam memimpin masyarakat sangat penting karena pengalaman kerja yang dimilikinya akan dapat membantu melaksanakan tugas tugas yang telah diamanahkan kepada mereka, maupun menjalakan program kerja dengan baik sesuai dengan target yang telah ditetapkan pemerintah daerah, memiliki kemampuan untuk mengambil keputusan dan berani mengambil resiko yang dihadapinya. Tujuan penelitian ini adalah untuk mengetahui motivasi dan pengalaman kerja pada Aparat Desa dalam pelaksanaan tugas pemerintahan desa di Kecamatan Pattallassang Kabupaten Gowa. Metode penelitian yang digunakan adalah pendekatan kualitatif. Teknik pengumpulan data adalah wawancara, dokumen dan observasi. Teknik analisis data adalah reduksi data, olah data dan penarikan kesimpulan. Hasil penelitian ini adalah motivasi yang diberikan kepada aparat desa baik oleh lingkungan maupun oleh Pemerintah Kecamatan sangat mendukung bagi peningkatan kinerja aparat, mereka akan lebih terdorong keinginannya untuk meningkatkan etos kerja mereka. Pengaruhnya terhadap kinerja tidak signifikan. Pengalaman kerja yang dimiliki oleh seorang aparat berpengaruh paling signifikan terhadap kinerja aparat desa secara parsial, semakin lama seorang aparat memegang jabatan, maka akan semakin banyak pula pengalaman yang mereka miliki.
\end{abstract}

KATA KUNCI: Motivasi, pengalaman kerja, program kerja, resiko

ABSTRACT: Motivation and work experience that a village official has in leading the community is very important because his work experience will be able to help carry out the task that has been entrusted to them, as well as to run a good work program in accordance with the targets set by the local government, have the ability to make decisions and dare to take risks faced. The purpose of this research is to find out the motivation and work experience in the Village Apparatus in the implementation of village government tasks in Pattallassang Subdistrict, Gowa Regency. The research method used is qualitative approach. Data collection techniques are interviews, documents and observations. Data analysis techniques are data reduction, data processing and conclusion drawing. The result of this research is the motivation given to village officials both by the environment and by the District Government is very supportive for the improvement of the performance of the apparatus, they will be more encouraged by their desire to improve their work ethic. The effect on performance is insignificant. The work experience possessed by an official has the most significant effect on the partial performance of village officials, the longer an officer holds office, the more experience they have.

KEYWORDS: Motivation, work experience, work programs, risks 


\section{PENDAHULUAN}

Kinerja dalam oraganisasi merupakan jawaban dari berhasil atau tidaknya tujuan organisasi yang telah ditetapkan. Para pimpinan atau manajer sering tidak memperhatikan kecuali sudah amat buruk atau segala sesuatu jadi serba salah. Terlalu sering para pimpinan atau manajer tidak mengetahui betapa buruknya kinerja telah merosot sehingga organisasi/ instansi menghadapi krisis yang serius. Kesan-kesan buruk organisasi yang mendalam berakibat dan mengakibatkan tanda-tanda peringatan adanya kinerja yang merosot. Pada dasarnya kinerja Aparat Desa tidak cukup dengan peningkatan pendidikan dan pelatihan saja, tetapi bisa juga dilakukan melalui peningkatan motivasi kepada mereka. Timbulnya motivasi pada diri seseorang tentu oleh adanya suatu kebutuhan hidupnya baik itu kebutuhan primer maupun kebutuhan sekundernya. Jika kebutuhan tersebut dapat terpenuhi, maka seseorang akan giat bekerja sehingga kinerja dapat meningkat.

Kinerja aparat desa sebagai aparatur pemerintahan desa khusunya desa Sunggumanai tentu dipengaruhi oleh kebutuhan seperti yang dimaksud di atas, dan mereka akan bekerja keras jika pekerjaannya itu dapat memenuhi kebutuhan tersebut. Disamping faktor motivasi juga faktor pengalaman kerja sebagai aparat desa akan ikut mempengaruhi prestasi mkerja (kinerja) dalam pelaksanaan tugas kepemerintahan desanya. Aparat Desa yang sudah lama bekerja sebagai aparat desa akan lebih berpengalaman dibandingkan dengan yang baru bekerja sebagai aparat desa, dan dengan pengalaman tersebut ia akan mudah melaksanakan tugas kesehariannya sebagai aparatur pemerintahan desa.

Menurut (Basu Swastha dan Irawan, 2005) bahwa kinerja (performance) adalah hasil kerja yang bersifat konkret, dapat diamati, dan dapat diukur. Jika kita mengenal tiga macam tujuan, yaitu tujuan organisasi, tujuan unit, dan tujuan pegawai, maka kita juga mengenal tiga macam kinerja, yaitu kinerja organisasi, kinerja unit, dan kinerja pegawai. (Dessler, 2013) berpendapat: Kinerja (prestasi kerja) karyawan adalah prestasi aktual karyawan dibandingkan dengan prestasi yang diharapkan dari karyawan. Prestasi kerja yang diharapkan adalah prestasi standar yang disusun sebagai acuan sehingga dapat melihat kinerja karyawan sesuai dengan posisinya dibandingkan dengan standar yang dibuat. Selain itu dapat juga dilihat kinerja dari karyawan tersebut terhadap karyawan lainnya. Kinerja juga dapat menginterpretasikan perubahan lingkungan internal dan eksternal berdasarkan kompetensi sumber daya manusia, kapabilitis organisasi, manajemen pengetahuan, dan pengalaman (Henni Zainal, Muhammad Rakib, Andi Idham Ashar, Darmawati Manda, Andi Tenry Sose, 2020; Henni Zainal, Parinsi, Indonesia, Hasan, \& Makassar, 2018; Rakib, Zainal, Farwita, \& Yusriadi, 2019; Zainal, 2017).

Berdasarkan beberapa teori tentang kinerja dan prestasi kerja dapat disimpulkan bahwa pengertian kinerja maupun prestasi kerja mengandung substansi pencapaian hasil kerja oleh seseorang. Dengan demikian bahwa kinerja maupun prestasi kerja merupakan cerminan hasil yang dicapai oleh seseorang atau sekelompok orang. Kinerja adalah suatu hasil kerja yang dihasilkan oleh seorang karyawan diartikan untuk mencapai tujuan yang diharapkan.

Motivasi terbentuk dari sikap (attitude) seorang pegawai dalam menghadapi situasi kerja. Motivasi merupakan kondisi yang menggerakkan diri pegawai yang terarah untuk mencapai 
tujuan organisasi. Sikap mental merupakan kondisi mental yang mendorong diri pegawai untuk berusaha mencapai kinerja secara maksimal. Sikap mental seorang pegawai harus siap secara psikofisik (siap secara mental, fisik, tujuan dan situati), artinya seorang pegawai harus siap mental, maupun secara fisik, memahami tujuan utama dan target kerja yang akan dicapai, mampu memanfaatkan, dan menciptakan situasi kerja.

Menurut (Mangkunegara, 2000) mengemukakan pengertian kinerja sebagai berikut: Kinerja adalah hasil kerja secara kualitas dan kuantitas yang dicapai oleh seorang karyawan dalam melaksanakan tugasnya sesuai dengan tanggung jawab yang diberikanya. Pengalaman kerja juga menjadi salah satu faktor dalam mendukung kinerja seorang pegawai. Menurut (Wibowo, 2010) seorang pemimpin harus memiliki pengalaman mengorganisasi orang, komunikasi di hadapan kelompok, menyelesaikan masalah, dan sebagainya. Pengalaman yang dimiliki seseorang dari waktu ke waktu terus berubah sejalan dengan perjalanan waktu dan perubahan lingkungan.

\section{METODE PENELITIAN}

Penelitian ini dilakukan dengan penggunaan pendekatan kualitatif. Teknik pengumpulan data adalah wawancara, observasi dan dokumen. Teknik analisis ada dengan reduksi, oleh data dan penarikan kesimpulan. Wawancara digunakan dengan melakukan interview sejumlah pejabat yang ada di lingkungan Pemerintah Daerah guna menghasilkan informasi yang lebih akurat.

\section{HASIL DAN PEMBAHASAN}

Motivasi adalah memiliki tanggung jawab pribadi yang tinggi, memiliki semangat kerja yang tinggi, memiliki keinginan untuk berprestasi, dan memiliki semngat dalam melaksanakan program kerja yang telah ditetapkan pemerintah daerah. Penjelasan responden untuk masing-masing indicator dari variabel motivasi adalah sebagian besar dari responden atau sebanyak 58,97\% menjawab bahwa sangat diperlukan tanggung jawab pribadi yang sangat tinggi pada setiap aparat desa dalam melaksanakan tugas-tugasnya sesuai dengan amanah yang telah diberikan oleh masyarakat.

Penjelasan responden mengenai pentingnya aparat desaa memiliki semangat kerja yang tinggi didalam melaksanakan tugas-tugasnya selaku aparat desa sebanyak $61,54 \%$ menjawab penting karena semangat kerja yang tinggi perlu dimiliki setiap aparat desa agar tugas dan pekerjaan yang telah diberikan kepada mereka dapat dilaksanakan dengan lebih baik. Penjelasan responden mengenai keinginan yand ada dalam diri aparat desa untuk berprestasi sebanyak 79,49\% menjawab sangat penting karena mereka selalu berupaya agar setiap tugas dan rencana kerja yang telah ditargetkan pemerintah daerah harus dapat dilaksanakan dengan hasil yang terbaik.

Penjelasan responden mengenai perlunya setiap aparat desa memiliki semangat dalam melaksanakan program kerja yang telah ditetapkan pemerintah daerah sebanyak 43,59\% menjawab perlu, agar program kerja yang telah ditetapkan pemerintah daerah dapat dilaksanakan dengan baik oleh setiap aparat desa. pengalaman kerja adalah lamanya masa kerja sebagai aparat desa, memiliki pengalaman memimpin bawahan, memiliki pengalaman sebagai 
aparatur pemerintah, dan memiliki pengalaman dalam bidang administrasi.

Penjelasan responden mengenai masa kerja yang dimiliki sangat membantu tugas dan pekerjaan selaku aparat desa sebanyak $56,41 \%$ menjawab setuju karena apabila seseorang yang memangku jabatan belum cukup lama akan mengakibatkan seseorang itu belum mengenal dan menghayati pekerjaan yang diembannya. Penjelasan responden mengenai Pengalaman kerja berpengaruh terhadap kinerja seorang aparat desa dalam pelaksanaan tugas pemerintahan sebanyak 56,41\% menjawab sangat berpengaruh karena pengalaman kerja akan melahirkan kemampuan dalam menjalankan tugas pemerintahan yang akan sangat mendukung keberhasilan seorang aparat desa dalam menjalankan tugas dan tanggung jawabnya.

Penjelasan responden mengenai pengalaman sebagai aparatur pemerintah sebanyak 46,9\% menjawab tidak setuju karena sebagian besar aparat desa yang terpilih di Kecamatan Pattallassang adalah berasal dari pemilihan langsung oleh rakyat dan bukan berasal dari kalangan aparatur pemerintah. Penelitian terdahulu mengemukakan bahwa motivasi mempengaruhi kinerja pegawai secara signifikan. Hal ini menjelaskan bahwa manajemen puncak memusatkan perhatian pada motivasi sehingga akan membawa pemimpin menuju peningkatan kinerja pegawai yang positif. (Bashir, n.d.; Hashim Zameer et all, 2014)

Penjelasan responden mengenai pengalaman yang dimiliki dalam bidang administrasi sebagai aparat desa sebanyak $51,28 \%$ menjawab sangat setuju karena seorang aparat desa yang terpilih harus mengerti dan memahami administrasi pemerintahan desa agar dapat menjalankan tugas dan pekerjaan dengan baik.

\section{PENUTUP}

Motivasi atau dorongan atau support yang diberikan kepada aparat desa baik oleh lingkungan maupun oleh Pemerintah Kecamatan sangat mendukung bagi peningkatan kinerja aparat, mereka akan lebih terdorong keinginannya untuk meningkatkan etos kerja mereka. Pengaruhnya terhadap kinerja tidak signifikan. Pengalaman kerja yang dimiliki oleh seorang aparat berpengaruh paling signifikan terhadap kinerja aparat desa secara parsial, semakin lama seorang aparat memegang jabatan, maka akan semakin banyak pula pengalaman yang mereka miliki.

\section{DAFTAR PUSTAKA}

Bashir, U. (n.d.). Impact of Stress on Employees Job Performance A Study on Banking Sector of Pakistan, 122-126.

Basu Swastha dan Irawan. (2005). Asasasas Marketing. Yogyakarta: Liberty.

Dessler. (2013). Manajemen Sumber Daya Manusia Human Reources. Jakarta: Prenhalindo.

Hashim Zameer et all. (2014). The impact ot the motivation on the employee's performance in Beverage Industry of Pakistan. International Journal of Academik Research in Accouting, Finance and Management Sciences, 4(1).

Henni Zainal, Muhammad Rakib, Andi Idham Ashar, Darmawati Manda, Andi Tenry Sose, I. S. (2020). Strategy of human resources development in improving performance Apparatus in the Bone Regency Regional Inspectorate. Pinisi Business Administration Review, 2(1). 
Henni Zainal, U. I. T., Parinsi, W. K., Indonesia, S. P., Hasan, M., \& Makassar, U. N. (2018). The Influence Of Strategic Assets And Market Orientation To The Performance Of Family Business In Makassar City , Indonesia, 17(6), 1-9.

Mangkunegara, A. A. (2000). Manajemen Sumber Daya Manusia Perusahaan. Bandung: PT Remaja Rosdakarya.

Rakib, M., Zainal, H., Farwita, S., \& Yusriadi, Y. (2019). The Improvement of Employees ' Performance in South Sulawesi, Indonesia, (November). https://doi.org/10.35940/ijrte.D 7761.118419

Wibowo. (2010). Manajemen Kinerja. Jakarta: Rajawali Pers.

Zainal, H. (2017). Influence of Work Motivation and Discipline on Work Productivity, 149 (Icest), 25-27. 